\title{
Effect of plant growth regulators on growth, yield and fruit quality of strawberry (Fragaria $x$ ananassa Duch.) under protected conditions
}

\author{
Yash Thakur $^{1 *}$, J. S. Chandel ${ }^{1}$ and Pramod Verma ${ }^{11}$ \\ Department of Fruit Science, Dr Yashwant Singh Parmar University of Horticulture and Forestry, Nauni, Solan - 173230 \\ (H.P.), INDIA \\ *Corresponding author E-mail: thakuryash0211@gmail.com \\ Received: July 24, 2016; Revised received: April 29, 2016; Accepted: August 10, 2017

\begin{abstract}
A field trial was conducted during 2015 and 2016, to study the effect ofgrowth regulators on growth, flowering, yield and fruit quality of strawberry cv. Chandler. The experiment was laid out in completely randomized design with 16 treatments viz.CPPU at 1, 2 and $4 \mathrm{ppm}, \mathrm{GA}_{3}$ at 25, 50 and $75 \mathrm{ppm}$,Promalin at 2, 4 and 6 ppm, GA $4+7$ at 5, 10 and15 ppm, NAA at 10, 20 and $30 \mathrm{ppm}$ and control (water spray) and each treatment was replicated thrice. The results revealed that the plants sprayed with $15 \mathrm{ppm} \mathrm{GA}_{4+7}$ two weeks before flowering significantly reported highest plant height $(33.43 \mathrm{~cm})$, leaf area $\left(239.70 \mathrm{~cm}^{2}\right)$, number of flowers $(31.94)$, fruit set $(87.45 \%)$, number of fruits per plant $(29.02)$, yield $(540.01 \mathrm{~g} / \mathrm{plant})$, fruit length $(53.63 \mathrm{~mm})$ and fruit diameter $(37.19 \mathrm{~mm})$ and fruit weight $(23.70 \mathrm{~g})$ as compared to control. This treatment resulted in $196.36 \%$ increase in yield and $56.22 \%$ in fruit weight over control. Plants sprayed with $6 \mathrm{ppm}$ promalin also showed significant improvement in vegetative growth, fruit control. Hence, it is concluded that foliar spray of $15 \mathrm{ppm} \mathrm{GA} 4+7$ applied 2 weeks before flowering is beneficial in improving growth, yield and fruit quality of strawberry plants.
\end{abstract} \\ size, yield and fruit quality, which resulted in $137.92 \%$ increase in yield and $51.81 \%$ increase in fruit weight over
}

Keywords: CPPU, $\mathrm{GA}_{3}, \mathrm{GA}_{4+7}, \mathrm{NAA}$, Promalin, Strawberry

\section{INTRODUCTION}

Strawberry (Fragaria $x$ ananassa Duch.) belongs to the family Rosaceae, is one of the important soft fruit of the world and has resulted from a cross between two wild strawberries: Fragaria virginiana (Meadow strawberry) and Fragaria chiloensis (Chilean strawberry). It is a herbaceous perennial plant which can be successfully cultivated in wide range of agro-climatic conditions from subtropics to temperate climate (Singh et al., 2006). Strawberry is highly remunerative fruit and gives high returns per unit area in the shortest possible time. Its fruit are in great demand for fresh market as well as in processing industry. In India, it is grown commercially in the states of Maharashtra, Punjab, Haryana, Karnataka, Madhya Pradesh, Jammu \& Kashmir, Himachal Pradesh and Uttrakhand.

The most commonly grown cultivar in the country is Chandler which is a short day variety and gives higher production of quality fruits. Strawberry cultivation is mainly done in the open field conditions, which resulted in production of poor size and quality fruits, however, for higher fruit production of better quality fruits, its cultivation can be done under protective conditions. Growth regulators have also been reported to play an important role in sustainable quality fruit production in fruit crops (Kumar et al., 2013). Besides cultural practices, plant growth regulators can effectively be used for the improvement of vegetative growth, flowering, yield and fruit quality of strawberry. Keeping in view all these facts, the experiment was conducted to assess the effect of plant growth regulators on growth, yield and fruit quality of strawberry under protected conditions.

\section{MATERIALS AND METHODS}

The present investigation was undertaken in the Department of Fruit Science, Dr. Y. S. Parmar University of Horticulture and Forestry Nauni, Solan H.P. during 2014-2015 and 2015-2016 under protected conditions. Prior to the preparation of beds, the land was thoroughly prepared by repeated ploughing with the help of power tiller and well rotten FYM @ $60 \mathrm{~kg} / \mathrm{m}^{2}$ area was incorporated in the soil. The raised beds $2 \mathrm{~m} x$ $2 \mathrm{~m}$ size were prepared and thirty two healthy runners of strawberry cultivar Chandler were planted in these beds at a spacing of $50 \mathrm{~cm} \times 25 \mathrm{~cm}$ during the first week of October 2014 and again in the first week of October 2015 for second year experiment as the crop was grown as annual crop. The uniform cultural practices like weeding, hoeing, irrigation and mulching were done at regular intervals to all the plants. The growth regulators consisting of CPPU [N-(2-chloro-4pyridyl)-N'-phenyl urea] at 1,2 and 4 ppm; $\mathrm{GA}_{3}$ 
(Gibberellic acid) at 25, 50 and $75 \mathrm{ppm}$; Promalin at 2, 4 and 6 ppm; $\mathrm{GA}_{4+7}$ at 5, 10 and 15 ppm; NAA (Naphthalene -3- acetic acid)at 10, 20 and 30 ppm andcontrol (water spray) were sprayed 2 weeks before flowering. In all there were 16 treatments and each treatment was replicated thrice in a Completely Randomized Block Design.

The observations on different vegetative growth, fruiting, yield and quality parameters were measured. The height of plants was measured with a measuring scale from the crown level to the apex of primary leaves and results were expressed as average height in centimeters (cm). The leaf area was measured with the help of LICOR 3100 leaf area meter and average leaf area was expressed in square centimeter $\left(\mathrm{cm}^{2}\right)$. The vegetative characteristics viz. plant height and leaf area was recorded at the end of fruiting, when plant attain full growth. The floral characteristics were recorded during the flowering season. The $\%$ fruit set per plant was calculated by using formula given by Westwood (1993). The number of fruits per plant was counted at time of fruit maturity. The weight of entire fruits harvested per plant was recorded for each treatment and accordingly, yield per plant was worked out. The fruit size and weight of ten randomly selected berries was determined and average was worked out. The quality parameters like total soluble solids were determined with the help of a hand refractrometer. The titratable acidity and sugar contents were determined by volumetric methods given by Ranganna (1995), while the anthocyanin content in the berry was determined by absorbance method (Harborne, 1973).The two years data were pooled and statistically analyzed with the standard procedure as suggested by Gomez and Gomez (1984). The level of significance for different variables was tested at $5 \%$ value of significance.

\section{RESULTS AND DISCUSSION}

The pooled data presented in Table 1 revealed that plant growth regulators exerted significant effect on plant growth of strawberry. The maximum plant height $(33.43 \mathrm{~cm})$ and leaf area $\left(239.70 \mathrm{~cm}^{2}\right)$ was recorded in plant sprayed with $15 \mathrm{ppm} \mathrm{GA}_{4+7}$. Whereas, the minimum plant height and leaf area was observed in control, recording $24.24 \mathrm{~cm}$ and $184.97 \mathrm{~cm}^{2}$, respectively. Plant sprayed with 15 ppm GA $4+7$ resulted in $37.91 \%$ of plant height and $29.59 \%$ of leaf area.The higher plant height and leaf area with the spray of $\mathrm{GA}_{4+7}$ in the present study may be due to increased cell elongation and division as gibberellic acid is known to stimulated the growth of plants by cell elongation (Turner, 1963). GA also reported to increase photosynthetic activity (Salisbury and Ross, 1986) which may account for higher leaf area. These results are in conformity with those of Saima et al. (2014) who also recorded significant increase in height and leaf area of strawberry plants sprayed with $75 \mathrm{ppm}$ of gibberellic acid, as compared to other treatments of gibberellic acid treatment of $50 \mathrm{ppm}$ and $100 \mathrm{ppm}$, naphthalene acetic acid applied at $25 \mathrm{ppm}, 50 \mathrm{ppm}$ and $75 \mathrm{ppm}$, cycocel applied at $500 \mathrm{ppm}, 750 \mathrm{ppm}$ and $1000 \mathrm{ppm}$ and control (distilled water).

Similarly, in the present study application of promalin also significantly increased the plant height and leaf area in comparison to control. Promalin applied at 6 ppm resulted in increase of $37.38 \%$ plant height and $24.10 \%$ of leaf area. $\mathrm{GA}_{4+7}+\mathrm{BA}$ are the major constituent of promalin, $\mathrm{BA}$ and $\mathrm{GA}_{4+7}$ plays role in cell division, differentiation and elongation (Whiting and Roll, 2015), therefore, the increased plant height and leaf area in present study may be due to cumulative effect of BA and gibberellic acid in cell division and cell elongation. Similar increase in plant height and spread with the application of promalin has also been reported byRadivojevic et al. (2015) in apple. They reported $15.13 \%$ increase in nursery tree height in tree sprayed with $1500 \mathrm{ppm} \mathrm{BA}+\mathrm{GA}_{4+7}$ over other treatments of $\mathrm{BA}+\mathrm{GA}_{4+7}$ and $\mathrm{BA}$ alone.

It is evident from the data presented in Table 1, the maximum number of flower(31.94) was obtained with the spray of $15 \mathrm{ppm} \mathrm{GA}_{4+7}$ and minimum number of flower (17.73) was recorded in control. The increase in number of flowers with the spray of $\mathrm{GA}_{4+7}$ may be due to more growth of inflorescence which might have resulted in production of more flowers. Similarly, the maximum fruit set $(87.45 \%)$ was recorded in plants sprayed with 15 ppm $\mathrm{GA}_{4+7-}$, and minimum fruit set $(75.71 \%)$ was obtained in control. These results are in accordance with the findings of Saima et al. (2014), who also recorded significant increase of $60.06 \%$ in flower numberand $22.97 \%$ of fruit set in strawberry plants with the application of gibberellic acid over control. Similarly, increased flower number and fruit set of $56.06 \%$ and $13.79 \%$, respectively was also obtained with the application of $6 \mathrm{ppm}$ promalin in present study. McArtney et al. (2014) also recorded increase in flower number and fruit set with the foliar spray of promalin in apple.

The data pertained in Table 1, showed that the highest number of fruits (29.02) and yield (540.01 g) per plant was recorded in plant sprayed with 15 ppm $\mathrm{GA}_{4+7}$. However, the minimum number of fruits (14.99) and yield per plant (182.21 g) was obtained in control. Higher fruit set andsize with the spray of $15 \mathrm{ppm}$ $\mathrm{GA}_{4+7}$ in the present study might have accounted for higher yield. The present findings are in conformity with those of Roussos et al. (2009) and Saima et al. (2014), who recorded significant increase in number of fruits and yield of strawberry with the application of gibberellic acid. Similarly, increased fruit number of $60.90 \%$ and yield increase of $159.07 \%$ was also observed with the application of $6 \mathrm{ppm}$ promalin over control in the present study (Table 1). The present 
Yash Thakur et al. / J. Appl. \& Nat. Sci. 9 (3): 1676 -1681 (2017)

Table 1. Effect of plant growth regulators on vegetative growth and fruiting in strawberry cv. Chandler

\begin{tabular}{|c|c|c|c|c|c|c|}
\hline Treatment & $\begin{array}{l}\text { Plant height } \\
\text { (cm) }\end{array}$ & $\begin{array}{c}\text { Leaf area } \\
\left(\mathrm{cm}^{2}\right)\end{array}$ & $\begin{array}{l}\text { Number of } \\
\text { flowers }\end{array}$ & $\begin{array}{c}\text { Fruit set } \\
(\%)\end{array}$ & $\begin{array}{c}\text { Number of } \\
\text { fruits per } \\
\text { plant }\end{array}$ & $\begin{array}{l}\text { Yield per } \\
\text { plant (g) }\end{array}$ \\
\hline & Pooled & Pooled & Pooled & Pooled & Pooled & Pooled \\
\hline $\mathrm{T}_{1}(\mathrm{CPPU} 1 \mathrm{ppm})$ & 27.47 & 197.83 & 23.30 & $\begin{array}{c}81.80 \\
(64.73)\end{array}$ & 18.56 & 261.90 \\
\hline $\mathrm{T}_{2}(\mathrm{CPPU} 2 \mathrm{ppm})$ & 28.74 & 203.65 & 23.50 & $\begin{array}{l}83.03 \\
(65.64)\end{array}$ & 18.88 & 279.31 \\
\hline $\mathrm{T}_{3}$ (CPPU 4 ppm) & 28.23 & 207.18 & 24.72 & $\begin{array}{c}83.68 \\
(66.15)\end{array}$ & 19.49 & 299.06 \\
\hline $\mathrm{T}_{4}\left(\mathrm{GA}_{3} 25 \mathrm{ppm}\right)$ & 29.84 & 211.98 & 25.35 & $\begin{array}{c}84.25 \\
(66.59)\end{array}$ & 20.02 & 321.96 \\
\hline $\mathrm{T}_{5}\left(\mathrm{GA}_{3} 50 \mathrm{ppm}\right)$ & 30.49 & 215.32 & 25.88 & $\begin{array}{c}85.23 \\
(67.38)\end{array}$ & 20.44 & 333.28 \\
\hline $\mathrm{T}_{6}\left(\mathrm{GA}_{3} 75 \mathrm{ppm}\right)$ & 30.55 & 221.09 & 27.22 & $\begin{array}{c}86.12 \\
(68.18)\end{array}$ & 21.76 & 341.67 \\
\hline $\mathrm{T}_{7}($ Promalin $2 \mathrm{ppm})$ & 29.99 & 225.96 & 26.68 & $\begin{array}{c}85.05 \\
(67.23)\end{array}$ & 22.90 & 393.19 \\
\hline $\mathrm{T}_{8}($ Promalin $4 \mathrm{ppm})$ & 31.47 & 234.45 & 30.26 & $\begin{array}{l}85.30 \\
(67.43)\end{array}$ & 25.64 & 433.53 \\
\hline $\mathrm{T}_{9}($ Promalin $6 \mathrm{ppm})$ & 33.30 & 229.54 & 27.67 & $\begin{array}{c}86.15 \\
(68.13)\end{array}$ & 24.12 & 472.06 \\
\hline $\mathrm{T}_{10}\left(\mathrm{GA}_{4+7} 5 \mathrm{ppm}\right)$ & 30.43 & 237.48 & 27.01 & $\begin{array}{c}85.78 \\
(67.83)\end{array}$ & 23.83 & 448.04 \\
\hline $\mathrm{T}_{11}\left(\mathrm{GA}_{4+7} 10 \mathrm{ppm}\right)$ & 30.57 & 238.16 & 28.34 & $\begin{array}{c}85.99 \\
(67.99)\end{array}$ & 24.57 & 464.03 \\
\hline $\mathrm{T}_{12}\left(\mathrm{GA}_{4+7} 15 \mathrm{ppm}\right)$ & 33.43 & 239.70 & 31.94 & $\begin{array}{c}87.45 \\
(69.23)\end{array}$ & 29.02 & 540.01 \\
\hline $\mathrm{T}_{13}$ (NAA $10 \mathrm{ppm}$ ) & 27.39 & 201.23 & 23.72 & $\begin{array}{c}78.25 \\
(62.18)\end{array}$ & 19.41 & 261.28 \\
\hline $\mathrm{T}_{14}(\mathrm{NAA} 20 \mathrm{ppm})$ & 27.75 & 207.08 & 23.92 & $\begin{array}{c}80.66 \\
(63.88)\end{array}$ & 20.43 & 300.86 \\
\hline $\mathrm{T}_{15}(\mathrm{NAA} 30 \mathrm{ppm})$ & 29.26 & 208.82 & 24.21 & $\begin{array}{c}82.54 \\
(65.27)\end{array}$ & 21.00 & 309.74 \\
\hline $\mathrm{T}_{16}$ (control) & 24.24 & 184.97 & 17.73 & $\begin{array}{c}75.71 \\
(60.45)\end{array}$ & 14.99 & 182.21 \\
\hline $\mathrm{CD}_{(0.05)}$ & 0.99 & 1.17 & 0.79 & 0.48 & 0.58 & 5.85 \\
\hline
\end{tabular}

*The figures in the parentheses are square root transformed values

finding on increased fruit number and yield was in accordance with the results obtained by those of Zurawicz et al. (2004) and Quintero et al.(2013) in strawberry who also obtained improvement in fruit number and yield with the application of promalin.

The pooled data indicates that plant growth regulators spray significantly increased the size and weight of strawberry in comparison to control (Table 2). The maximum length $(53.63 \mathrm{~mm})$ and breadth $(37.19 \mathrm{~mm})$ and weight $(23.70 \mathrm{~g})$ of fruits was recorded in plants sprayed with 15 ppmof $\mathrm{GA}_{4+7}$. The minimum fruit length, fruit breadth and fruit weight was observed in control, recording $38.76 \mathrm{~mm}, 27.89 \mathrm{~mm}$ and $15.17 \mathrm{~g}$, respectively. The present findings regarding the increase in fruit size and fruit weight with application of gibberellic acid are in consonance with results of Tripathi and Shukla (2006), who also reported increase in fruit size and weight of strawberry with application of gibberellic acid. The data also revealed that fruit size and weight was also significantly increased with the application of promalinin comparison to control in the present study (Table 2). Foliar spray of $6 \mathrm{ppm}$ produced the fruits having length of $52.62 \mathrm{~mm}$, diameter $33.94 \mathrm{~mm}$ and weight of $23.03 \mathrm{~g}$ which was significantly higher than control. The increase in fruit size and weight with application of promalin may be due to cell division and cell elongation. Al-madhagi et al. (2012) also found significant increase in fruit weight of $33.71 \%$ of strawberry with application of Promalin over control.

Application of gibberellic acid significantly increased total soluble solids and reduced the titratable acidity in fruits. Promalin also found to increase the total soluble solids in fruits. The maximum total soluble solid $\left(12.95{ }^{0} \mathrm{~B}\right)$ was registered with foliar application of 75 ppm $\mathrm{GA}_{3}$. Whereas, minimum total soluble solids $\left(9.51^{\circ} \mathrm{B}\right)$ was found in control in the present study (Table 2.). These results are in confirmatory with the findings of Thakur et al. (2015) also found significant increase in total soluble solids with the spray of 75 


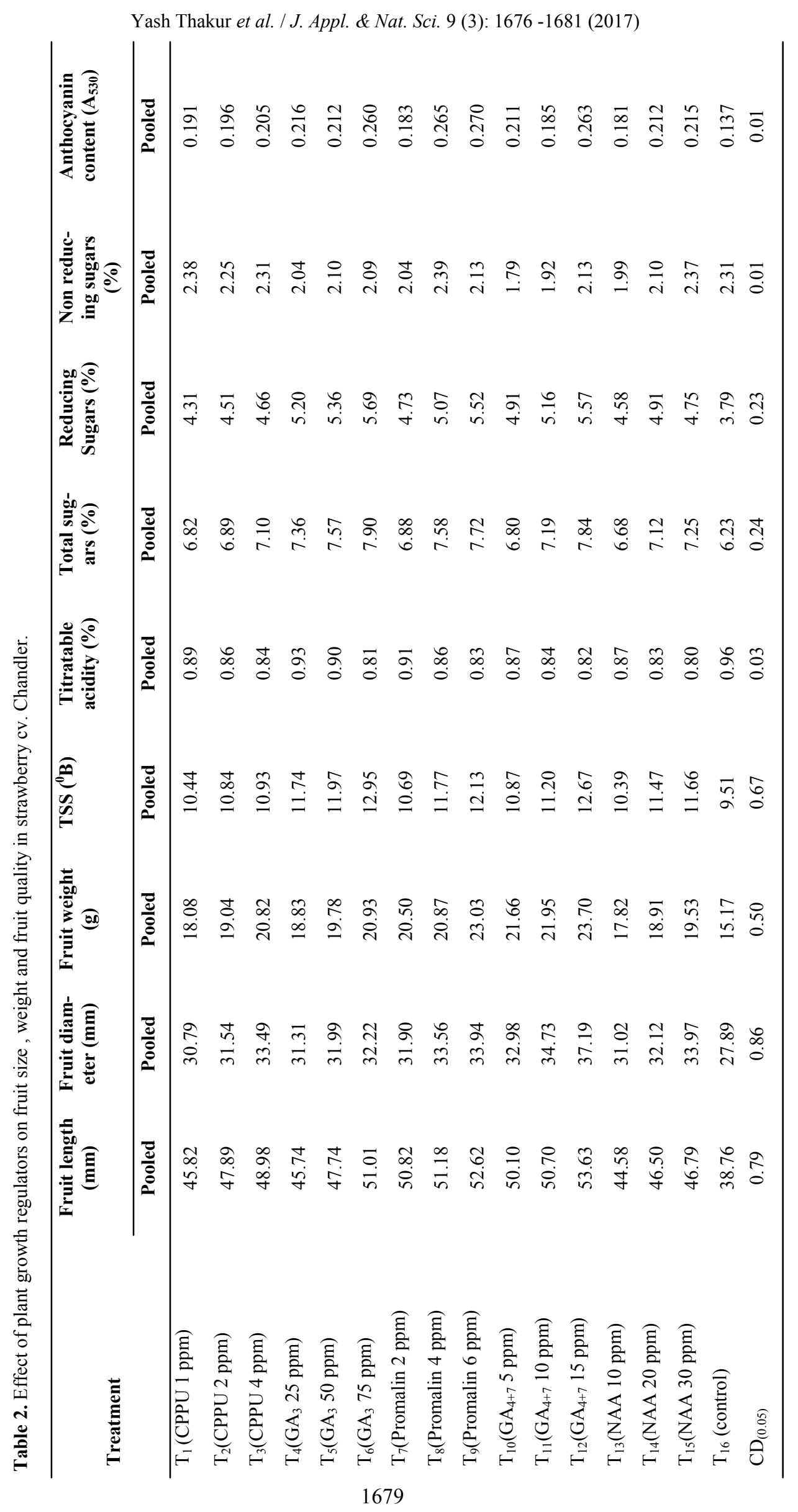


ppm $\mathrm{GA}_{3}$. The increase in TSS and titratable acidity with application of promalin in present study are in close conformity with results of Quintero et al. (2013) who also found significant increase in total soluble solids content in strawberry with the application of promalin.

The result of present study revealed that the sugars content was significantly increased with the foliar application of growth regulators (Table 2). Plants sprayed with $75 \mathrm{ppm} \mathrm{GA}$ resulted in increased total sugars content of $26.81 \%$ and reducing sugars of $50.12 \%$ over control. The maximum total sugars content $(7.90 \%)$ and reducing sugars $(5.69 \%)$ was recorded in $\mathrm{GA}_{3} 75 \mathrm{ppm}$, followed by $6 \mathrm{ppm}$ promalin. Whereas, maximum non-reducing sugars was recorded in $4 \mathrm{ppm}$ promalin treatment. These results are in conformity with those of Rana (2001) and Singh and Singh (2006) who also found significant increase in sugars content with higher concentration of gibberellic acid in strawberry plants.

Growth regulators significantly improved fruit colour of strawberry in terms of anthocyanin content (Table 2). The maximum anthocyanin content $\left(\begin{array}{lll}0.270 & \mathrm{~A}_{530}\end{array}\right)$ was found in plants treated with promalin at $6 \mathrm{ppm}$ and minimum anthocyanin content $\left(0.137 \quad \mathrm{~A}_{530}\right)$ was observed in control. The present finding are in close conformity with those of Quintero et al. (2013), who reported increased red colour intensity with application of promalin in strawberry cv. Albion. The increase in anthocyanin content was also found with the application of gibberellic acid in the present study. These results are in line with those of Roussos et al. (2009) who also observed enhanced anthocyanin content with application of gibberellic acid in strawberry plants. Further, the higher anthocyanin observed in the present study could be due to higher accumulation of carbohydrates due to increased photosynthesis under the influence of plant growth regulators.

\section{Conclusion}

On the basis of the results obtained in present investigation, it is inferred that the foliar spray of $15 \mathrm{ppm}$ $\mathrm{GA}_{4+7}$ applied 2 weeks before flowering, increase the flowering, fruit set, fruit length, fruit diameter, weight and yield by $80.14 \%, 15.51 \%, 38.36 \%, 33.35 \%$, $56.22 \%$ and $196.36 \%$ over control. The next best treatment was found $6 \mathrm{ppm}$ promalin which showed positive effect on improvement of fruit size, yield and fruit quality and resulted in the $137.92 \%$ increase in yield and $51.81 \%$ increase in fruit weight over control. Hence, application of $15 \mathrm{ppm}$ gibberellic acid 2 weeks prior to flowering is beneficial in improving growth, yield and fruit quality of strawberry plants

\section{REFERENCES}

Al-madhagi, I. A. H. Hasan, S. M. Z. Ahmad, A. Zain, A. M. and Yusoff, A. (2012). Influence of exogenous hormone on the flowering of strawberry (Fragaria $x$ ananassa Duch). Journal of Biology Agriculture and Healthcare, 2(4):46-52.

Gomez, K. A. and Gomez, A. A. (1984). In: Statistical Procedure for Agricultural Research $2^{\text {nd }}$ ed. New York: Willey Interscience, 304-309 pp.

Harborne, J. B. (1973). Phytochemical methods. Chapman and Haul InternationalEd. Toppan Co. Ltd. Tokyo, Japan.

Kumar, R. Saravanan, S. Bakshi, P. and Sharma, R. M. (2013). Influence of gibberellic acid and blossom removal on fruit quality of strawberry (Fragaria $x$ ananassa Duch.) cv. Belrubi. Society for Plant Research, 26(1): 107-110.

McArtney, S. Greene, D. Robinson, T. and Wargo, J. (2014). Evaluation of $\mathrm{GA}_{4+7}$ plus Benzyladenine as a frost-rescue treatment for apple. HortTechnology, 24(2): 1717-176.

Quintero, V. G. Herrara, A. J. and Alvarado, O. (2013). Effect of applications of gibberellins and 6- Benzylaminopurine on the production and quality of strawberry. Bioagro, 25(3): 194-200.

Radivojevic, D. D. Momirovic, I. S. Milivojevic, J. M. Velickovic, M. M. Oparnica, C. D. and Lukic, M. M. (2015). The influence of $\mathrm{BA}+\mathrm{GA}_{4+7}$ on formation of sylleptic shoots on one-year-old apple nursery trees. Journal of Agricultural Sciences, 60(1): 89-94.

Rana, R. K. (2001). Studies on the influence of nitrogen fixers and plant bio-regulators on growth, yield and fruit quality of strawberry cv. Chandler. Ph.D. Thesis, Dr. Y. S. Parmar University of Horticulture and Forestry, Solan, (HP) 77p.

Ranganna, S. (1995). Handbook of analysis and quality control for fruits andvegetable production. Tata McGraw Hill Publishing Company Limited NewDelhi pp. 1-21, 46-47, 68-70.

Roussos, P. A. Denaxa, N. K. and Damvakaris, T. (2009). Strawberry fruit quality attributes after application of plant growth stimulating compounds. Scientia Horticulturae 119(2): 138-146.

Saima, Z. Sharma, A. Umar, I. and Wali, V. K. (2014). Effect of plant bio-regulators on vegetative growth, yield and quality of strawberry cv. Chandler. African Journal of Agriculture Research,9(22): 1694-1699.

Salisbury, F. B. and Ross, C. W. (1986). Plant Physiology (Third edition). Wadsworth Publishing Company, Belmont, California, USA. pp. 309-349.

Singh, A. and Singh, J. N. (2006). Studies on influence of bio-fertilizers and bio-regulators on flowering, yield and fruit quality of strawberry cv. Sweet Charlie. Annals of Agricultural Research, 27(3): 261-264.

Singh, R. Asrey, R. and Kumar, S. (2006). Effect of plastic tunnel and mulching on growth and yield of strawberry. Indian Journal of Horticulture, 63(1): 18-20.

Thakur, S. Mehta, K. and Sekhar, S. R. (2015). Effect of GA 3 and plant growth promoting rhizobacteria on growth, yield and fruit quality of strawberry, Fragaria $x$ ananassa Duch. cv. Chandler. International Journal of Advanced Research, 3(11): 312-317.

Tripathi, V. K. and Shukla, P. K. (2006). Effect of plant bioregulators on growth, yield and quality of strawberry cv. 
Yash Thakur et al. / J. Appl. \& Nat. Sci. 9 (3): 1676 -1681 (2017)

Chandler. Journal of Asian Horticulture, 2(4): 260-263.

Turner, J. N. (1963). Application of gibberellic acid to strawberry plants at different stages of development. Nature, 197: 95-96.

Westwood, M. N. (1993). Temperate Zone Pomology. W.H. Freeman and Company, San Francisco. pp. 282.
Whiting, D. and Roll, M. (2015). Plant growth factors: plant hormones. Colorado Garden Show Inc., Colorado State University. 145p.

Zurawicz, E. Masny, A. and Basak, A. (2004). Productivity stimulation in strawberry by application of plant boregulators. Acta Horticulturae, 653: 155-159. 